\title{
Periphytic algae biomass at different shading levels: an experimental approach
}

\author{
Biomassa de algas perifíticas sob diferentes níveis de sombreamento: uma abordagem \\ experimental
}

\section{Helivania Sardinha dos Santos ${ }^{1 *}$ (i) and Liliana Rodrigues ${ }^{1}$ (1)}

\begin{abstract}
${ }^{1}$ Núcleo de Pesquisa em Limnologia, Ictiologia e Aquicultura - NUPÉLIA, Programa de Pós-graduação em Ecologia de Ambientes Aquáticos Continentais - PEA, Universidade Estadual de Maringá - UEM, Bloco G-90, Av. Colombo, 5790, CEP 87020-900, Maringá, PR, Brasil *e-mail: helivania@gmail.com
\end{abstract}

Cite as: Santos, H.S. and Rodrigues, L. Periphytic algae biomass at different shading levels: an experimental approach. Acta Limnologica Brasiliensia, 2021, 33, e9

\begin{abstract}
Aim: Light is an essential component in the process of synthesis of organic compounds by photosynthetic organisms. Assuming that a higher level of luminosity would positively influence the production of biomass, we evaluated the influence of different levels of shading on the biomass of periphytic algae, through an experimental study. Methods: Glass slides were used for this as an artificial substrate for the colonization and succession of algae in Garças Lake, on the upper Paraná River floodplain, and later transferred to nine aquaria. These were divided into three treatments: three without cover (AC), three with 50\% shading screens (A50) and three with $80 \%$ shading screens (A80). Abiotic variables $(\mathrm{pH}$, conductivity, turbidity, temperature and dissolved oxygen) and biomass were measured every five days for 15 days. The biomass was evaluated using the chlorophyll-a method. Concentrations of total phosphorus, phosphate, total nitrogen, nitrate and ammoniacal nitrogen were evaluated every five days. Results: There was no significant variation of the biomass over time, however, there is a significant difference between the treatments. The highest biomass was found in the control treatment and the lowest was found in the treatment with $80 \%$ shading. The other limnological variables evaluated did not show significant changes over time. Conclusions: The abiotic variables did not influence the biomass of the phycoperiphyton community, which was influenced only by luminosity. Thus, we conclude that light is a variable with direct influence on the production of periphytic biomass. At low intensity it is a variable that can limit the production of biomass. In high intensity however, it influences by increasing its production.
\end{abstract}

Keywords: luminosity; periphyton; experiment; chlorophyll- $a$.

Resumo: Objetivo: A luz é um componente essencial no processo de síntese dos compostos orgânicos por organismos fotossintetizantes. Acreditando que um maior nível de luminosidade influencia de maneira positiva na produção de biomassa, buscamos avaliar a influência de diferentes níveis de sombreamento sobre a biomassa de algas perifíticas, através de estudo experimental em mesocosmo. Métodos: Lâminas de vidro foram utilizadas como substratos artificiais para a colonização e sucessão das algas no Lago das Garças, planície de inundação do alto Rio Paraná, durante quinze dias, e posteriormente transferidos para nove aquários. Estes foram divididos em três tratamentos: três sem cobertura (AC), três com telas de sombreamento de 50\% (A50) e três com telas de $80 \%$ de sombreamento (A80). Variáveis abióticas ( $\mathrm{pH}$, condutividade, turbidez, temperatura e oxigênio dissolvido) e biomassa foram mensuradas a cada três dias, durante 15 dias. A biomassa foi avaliada através do método de clorofila- $a$. A cada cinco dias foram avaliadas as concentraçóes de fósforo 
total, fosfato, nitrogênio total, nitrato e nitrogênio amoniacal. Resultados: Não foi observada uma variação significativa da biomassa ao longo do tempo, entretanto, há uma diferença significativa entre os tratamentos. A maior biomassa média foi encontrada no tratamento controle e a menor foi encontrada no tratamento com $80 \%$ de sombreamento. As demais variáveis limnológicas avaliadas não apresentaram mudanças significativas ao longo do tempo. Conclusóes: As variáveis abióticas não influenciaram a biomassa da comunidade ficoperifítica, a qual foi influenciada apenas pela luminosidade. Assim, concluímos que a luz é uma variável com influência direta na produção de biomassa perifítica. Em baixa intensidade, é uma variável que pode limitar a produção de biomassa. Em alta intensidade, no entanto, influencia aumentando sua produção.

Palavras-chave: luminosidade; perifíton; experimento; clorofila- $a$.

\section{Introduction}

Light is an essential component in process of synthesis organic compounds by photosynthetic organisms. Its variation influences in different ways all the communities of a trophic web (Hill et al., 1995; Cadwell et al., 1998). Periphytic algae are photosynthetic organisms which contribute greatly to the primary productivity of aquatic ecosystems, and their biomass is present at several levels. (Vadeboncoeur \& Steinman, 2002; Guariento et al., 2011).

Periphytic algae constitute a very diversified group of organisms, both morphologically and physiologically. Among the characteristics that distinguish them, we can highlight the different photosynthetic pigments that absorb specific light lengths in the photosynthetic process, forcing the groups to respond in different ways to different intensities (Boston \& Hill, 1991). Thus, light can act in different ways on the development of the community of periphytic algae. For example, in low light it can limit the production of biomass of the community (Hill \& Fanta, 2008), as it can also lead to a photo-adaptation of these organisms to this type of environment (Hill \& Boston, 1991). A high level of brightness can cause increasing productivity (Guasch \& Sabater, 1998; Dodds et al., 1996), just as it can also act as a limiting factor, because high levels of light radiation can resulty in photoinhibition, limiting productivity, and even provoke the death of these organisms (Boston \& Hill, 1991; Antoine \& Benson-Evans, 1983b).

However, in order for periphytic algae to have access to light, some barriers must be crossed. In addition to the fact that part of solar radiation is lost in its passage through the atmosphere through, among other factors (Fontana et al., 2012), the intensity of radiation reaching periphytic algal communities is still affected by the presence of suspended substances in the water, including the shading generated by the riparian forests, by macrophytes and even by the community's self-shading generated by, for example, pedunculated algae (Hill, 1996; Cattaneo et al., 1998; Vis et al., 2006).

Numerous studies have already been carried out evaluating the influence of light on the communities of periphytic algae. However, many were realized in lotic environments, or in experiments simulating these environments (Wood et al., 2016; Winkworth et al., 2015; Krupek et al., 2014). Thus, there is a shortage of studies for lentic environments. In addition, a large part of the work in this type of environment has been carried out with the objective of evaluating the influence of multiple stressors, not only the light, but many are performed in situ, which makes it difficult to evaluate the factor that actually influence the community (Sanches et al., 2011; Antoine \& Benson-Evans, 1983a).

Therefore, it is necessary to carry out more controlled experiments in order to exclude as many factors as possible and, as such, seek to determine more effectively the influence of the desired factor. The objective of this study was to evaluate the influence of different levels of shading on the biomass of periphytic algae through an experimental study carried out in mesocosm simulating a lentic environment. We hypothesize that a higher level of luminosity will promote an increase in the production of photosynthetic biomass (Dodds et al., 1996), because a greater luminous intensity affecting the community of periphytic algae, will promote greater photosynthesis and greater biomass.

\section{Material and Methods}

The experiment consisted of two stages, one in situ and one in mesocosm, simulating lakes of tropical environments. The two stages occurred in the spring, between October and November 2014. During this period, the weather is predominantly sunny, temperatures rise and rains are sporadic. The tourism in the region is less, reducing the flow of boats, jet skis and fishing activities close to the places where we carry out the experiments. 


\subsection{Study area}

The study area (Figure 1), which was carried out in situ stage, Lake Garças, located in the State of Mato Grosso do Sul, at coordinates $22^{\circ} 43^{\prime} \mathrm{S}$ and $53^{\circ} 14^{\prime} \mathrm{W}$, in the Upper Paraná River floodplain. The plain has an area of about $230 \mathrm{~km}$ and is located between the dam of Porto Primavera and the reservoir of Itaipú (Agostinho et al., 2008). Lake Garças is about 2,000 m in length, $150 \mathrm{~m}$ wide and has an average depth of $2.5 \mathrm{~m}$. The lake is connected to the Paraná River through a channel about $100 \mathrm{~m}$ long.

\subsection{Sampling and analyzed variables (in situ and experiment)}

In the first stage of the experiment, glass slides on wood supports were used as artificial substrates for the colonization and establishment of the periphytic algae in the lake (Figure 2). These substrates were placed in a vertical position in relation to the water surface on wooden supports that remained submerged to a depth of approximately $15 \mathrm{~cm}$. The duration of this stage was 15 days, time required for community establishment (Rodrigues \& Bicudo, 2001; Murakami $\&$ Rodrigues, 2009). The support was placed in the limnetic region of the lake, close to a bank of the macrophyte Eichhornia azurea Kunth.

In the second stage, and under the same period, slides were removed from the support, fixed in polystyrene supports, placed into a cooler with ice to be transferred posteriorly to nine aquariums arranged in an open area at the advanced field study base of the Universidade Estadual de Maringá. The aquariums were filled with water from the lake itself, to preserve the characteristics of the environment where the slides were colonized, and each received 24 slides. In the aquariums, the substrates were placed in a vertical position in relation to the water

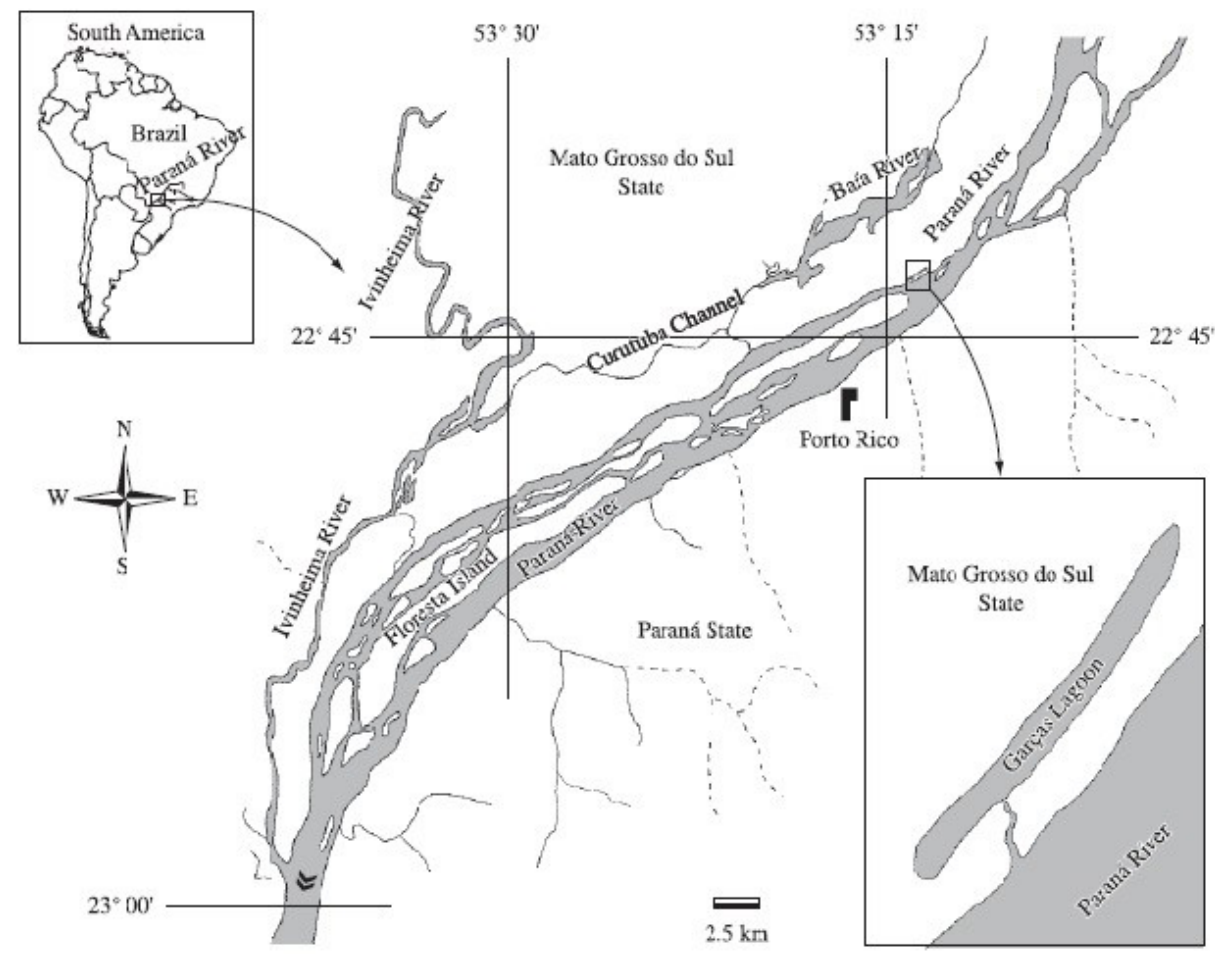

Figure 1. Location of study area, Lake Garças (Source: Murakami et al., 2009).

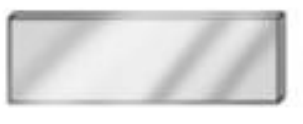

Artificial substrate (Glass slides)

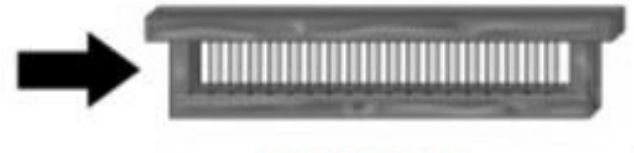

Wood supports

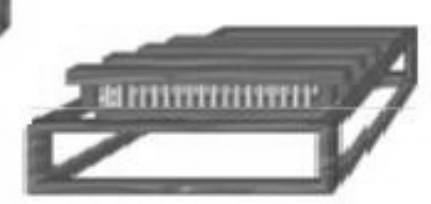

Figure 2. Artificial substrate used in the experiment (Adapted from Murakami, 2008). 
surface and remained submerged to a depth of approximately $10 \mathrm{~cm}$. To maintain oxygenation, aquarium pumps were used. The aquariums were divided into three treatments (Figure 3) at random: three received a cover that generates a light attenuation of about $80 \%$ (A80), three received a cover that generates a light attenuation of about 50\% (A50) and three were not covered (Control - AC). Sampling of the slides in the aquariums occurred on days 1, 3, 5, 7, 10, 13 and 15. For biomass analysis of each treatment, through the chlorophyll- $a$ method, a slide was randomly sampled from each aquarium.

In the aquaria, on days 5, 10 and 15 , water samples were taken to evaluate the following nutrients: total phosphorus, phosphate, total nitrogen, nitrate and ammoniacal nitrogen. Periphytic algae on the plain have a greater influence of these nutrients (Murakami \& Rodrigues, 2009). These variables were also measured in the pond prior to transfer to the aquariums. Water samples collected in the aquariums were analyzed in the laboratory. In this analysis we quantified total nitrogen and nitrate (Giné et al., 1980); ammoniacal nitrogen and ammonium (Koroleff, 1976); phosphate and total phosphorus (Mackereth et al., 1978).

In addition to the nutrients, the following variables were measured: $\mathrm{pH}$, conductivity, turbidity, temperature and dissolved oxygen, as well as luminous intensity. These abiotic variables were measured in loco, always in the morning, using portable devices (Digimed and YSI brands), and a light meter (Instrutherm brand) was used for the luminous intensity. Luminous radiation, measured above the water column.

The glass slides removed from the aquaria were scraped with a sheet of steel coated with aluminum foil, and the removed material was filtered on GF/C glass fiber filters, macerated in mortar with acetone (90\%) as a solvent and the obtained extract was centrifuged. Then, the supernatant was used to determine the concentrations of chlorophyll- $a$ ex situ by spectro-photometry (Golterman et al., 1978).

\subsection{Statistical analysis}

To evaluate if shading has a significant effect on periphytic algae productivity, a Factor Variance Analysis and a Post Hoc test, Tukey test at a significance level of 5\% was used. The test for homoscedasticity was performed previously (Levene test). To perform this analysis, we used Statistica 7.1 software (StatSoft Inc., 2005).

\section{Results}

The control treatment was the one with the highest mean value of biomass throughout the experiment $\left(0.233 \mu \mathrm{g} / \mathrm{cm}^{2}\right)$, followed by treatment with $50 \%$ shading $\left(0.149 \mu \mathrm{g} / \mathrm{cm}^{2}\right)$. The treatment with $80 \%$ shading produced the lowest average biomass $\left(0.129 \mu \mathrm{g} / \mathrm{cm}^{2}\right)$. The highest values of biomass were observed on the $10^{\text {th }}$ day $\left(0.327 \mu \mathrm{g} / \mathrm{cm}^{2}\right)$ and on the $15^{\text {th }}$ day of succession $\left(0.402 \mu \mathrm{g} / \mathrm{cm}^{2}\right)$ in the control treatment. The lowest values of biomass were observed on the $3^{\text {rd }}$ day $\left(0.064 \mu \mathrm{g} / \mathrm{cm}^{2}\right), 10^{\text {th }}\left(0.084 \mu \mathrm{g} / \mathrm{cm}^{2}\right)$, in the treatment with $80 \%$ shading, and on the $13^{\text {th }}$ day $\left(0.079 \mu \mathrm{g} / \mathrm{cm}^{2}\right)$ in the treatment with $50 \%$ shading.

The Factorial Variance Analysis, at a significance level of 5\%, showed that there was no significant variation of the biomass over time (F: 1.38, G.L: 6, p: 0.24). However, there is a significant difference between the treatments (F: 4.05, GL: 2, p: 0.024 Figure 4), and this difference occurred between the

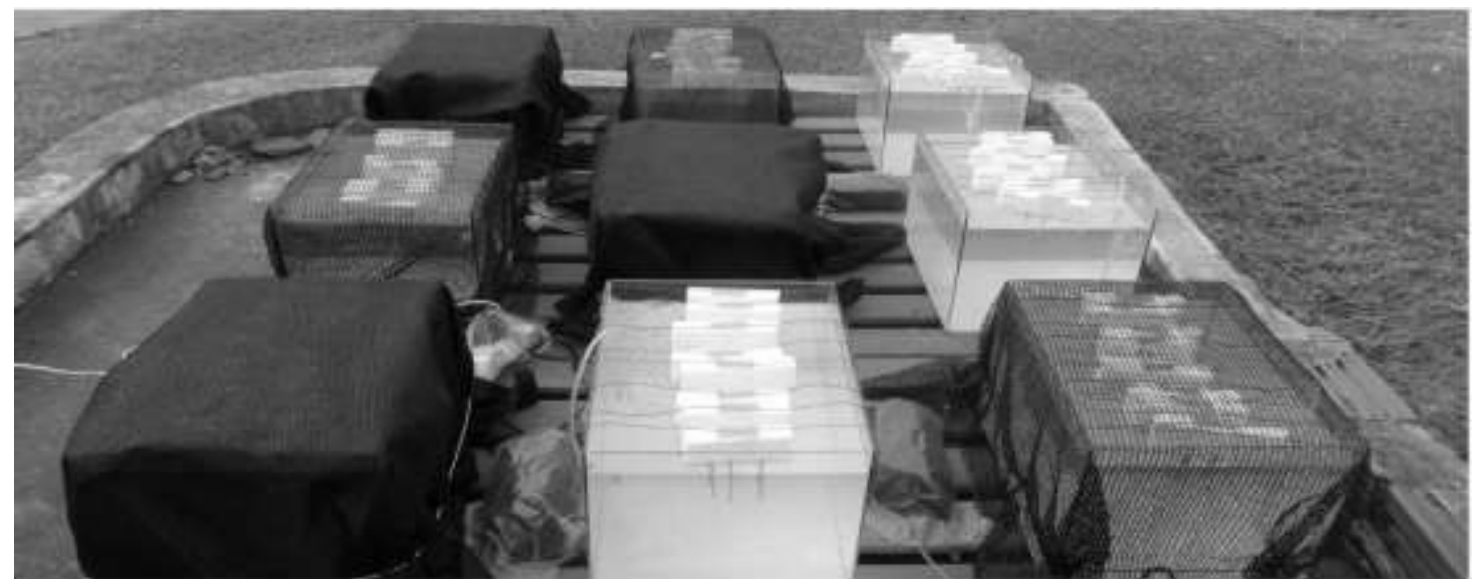

Figure 3. Random distribution of aquariums. 
Table 1. Mean values of abiotic variables at the beginning and end of the experiment in the three treatments (Control, Treatment with 50\% shading and Treatment with $80 \%$ shading).

\begin{tabular}{|c|c|c|c|c|c|c|}
\hline \multirow{2}{*}{ Abiotic Variables } & \multirow{2}{*}{$\begin{array}{l}\text { Day } 0 \\
\text { Lake }\end{array}$} & \multicolumn{3}{|c|}{ Day 05} & \multicolumn{2}{|c|}{ Day 15} \\
\hline & & C & $\mathrm{A} 50 \%$ & $\mathrm{~A} 80 \%$ & C & $\mathrm{A} 50 \%$ \\
\hline Temperature $\left({ }^{\circ} \mathrm{C}\right)$ & 29.5 & 27.1 & 26.1 & 25.9 & 25.5 & 24.7 \\
\hline Dissolved oxygen (mg. $\left.\mathrm{L}^{-1}\right)$ & 5.95 & 7.29 & 7.33 & 7.48 & 7.51 & 7.42 \\
\hline $\mathrm{pH}$ & 7.15 & 7.42 & 7.14 & 7.2 & 7.45 & 7.39 \\
\hline Conductivity $\left(\mu \mathrm{S} . \mathrm{cm}^{-1}\right)$ & 72.2 & 67.96 & 65 & 64.8 & 99.8 & 84.7 \\
\hline Turbidity (UNT) & 2.94 & 1.44 & 1.96 & 1.05 & 1.77 & 3.02 \\
\hline Total nitrogen $\left(\mu \mathrm{g} . \mathrm{I}^{-1}\right)$ & 102.85 & 104.11 & 104.26 & 107.37 & 123.75 & 108.48 \\
\hline Ammoniacal nitrogen $\left(\mu \mathrm{g} / \mathrm{l}^{-1}\right)$ & 24.94 & 4.72 & 11.66 & 17.69 & 4.64 & 9.42 \\
\hline Nitrate $\left(\mu \mathrm{g} . \mathrm{I}^{-1}\right)$ & 0.02 & 0.02 & 0.02 & 0.03 & 0 & 0 \\
\hline Total phosphorus $\left(\mu \mathrm{g} . \mathrm{I}^{-1}\right)$ & 32.29 & 22.77 & 15.30 & 13.58 & 24.92 & 19.38 \\
\hline Phosphate $\left(\mu \mathrm{g} . \mathrm{I}^{-1}\right)$ & 24.12 & 5.53 & 5.16 & 4.67 & 7.35 & 6.36 \\
\hline
\end{tabular}

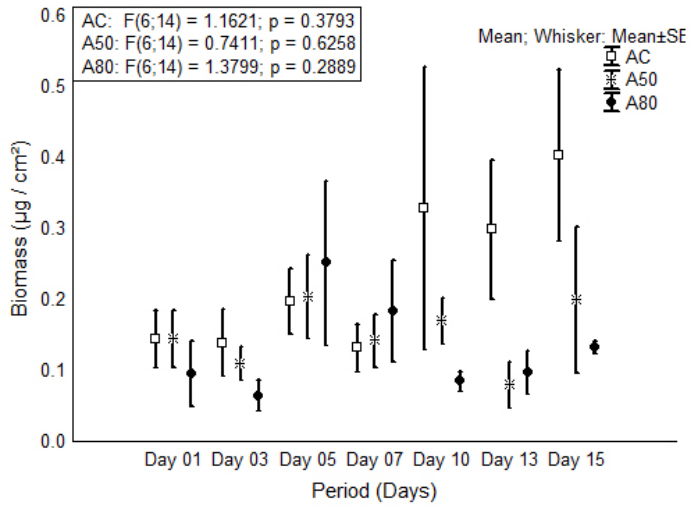

Figure 4. Variation of the biomass of the periphytic algae in the different treatments (AC: Control Treatment, A50: Treatment with 50\% shading, A80: Treatment with $80 \%$ shading) over time.

Table 2. Mean values of luminous intensity in the treatments (Control, A50\%: Aquarium with 50\% coverage, A80\%: Aquarium with $80 \%$ coverage) throughout the experiment.

\begin{tabular}{ccc}
\hline Treatments & \multicolumn{2}{c}{ Light $\left(\boldsymbol{\mu m o l} . \mathrm{m}^{-2} \cdot \mathbf{s}^{-1}\right)$} \\
\cline { 2 - 3 } & Day $\mathbf{0 5}$ & Day $\mathbf{1 0}$ \\
\hline Control & 1484 & 1543 \\
A50\% & 852 & 760 \\
A80\% & 202 & 177 \\
\hline
\end{tabular}

control treatments and with $80 \%$ shading according to the Post Hoc test, Tukey test at a significance level of 5\% (p: 0.0278).

Some variables showed variation between the beginning and the end of the experiment, like conductivity in all the treatments. In the treatment with $50 \%$ of shading, there was also a variation in relation to the turbidity. There was a greater variation of turbidity and ammoniacal nitrogen in the treatment with $80 \%$ shading (Table 1). Luminous radiation, measured above the water column, can have its results observed in detail in Table 2.

\section{Discussion}

Light is a limiting factor for the productivity of periphytic algae. In our work, we observed that the availability of more light was a determining factor for the increased production of biomass, and the average yield occurred in the treatment with the highest light availability, without cover, which was our control treatment. Higher light availability was also noted as a determinant for the increase of chlorophyll- $a$ in a study conducted in a dark water lentic environment, due to a large amount of dissolved organic material, and so was the main factor regulating periphytic biomass (Sanches et al., 2011). The same was observed in the study conducted in a tropical reservoir, with mesotrophic characteristics, during the dry season. As a result of the higher light incidence, due to the reduction in the percentage of macrophytic bank coverage, there was a greater increase in biomass and periphytic growth (Pellegrini \& Ferragut, 2012).

Some studies show that high intensity of light radiation can cause photoinhibition, reducing the production of biomass (Zhao et al., 2018; Wellnitz et al., 1996) but which did not occur in our experiment. This can be explained through our study by the fact that the community has already developed in an environment with high luminosity; the biofilm was already well developed when the substrates were transferred to the aquariums and, thus, the highest luminous intensity was attenuated by the self-shading of the community, protecting the lower layers of the photo-inhibition process, allowing them to produce biomass more efficiently (Hill \& Boston, 1991). According to studies carried out by Boston \& Hill (1991), photoinhibition in periphytic algae occurs significantly at a light intensity above $1100 \mu \mathrm{mol} \cdot \mathrm{m}^{-2} \cdot \mathrm{s}^{-1}$, however, high luminosity was not a factor that generated this 
process in the evaluated community, because the average value of the light intensity in the experiment did not exceed $1543 \mu \mathrm{mol} \cdot \mathrm{m}^{-2} \cdot \mathrm{s}^{-1}$.

There was no significant variation in community biomass over time. The variation on the fifth day of the aquarium experiment, which corresponds to the 20th day of colonization, can be explained by the variation in the community structure that occurs during the succession process, resulting in an increase in biomass, which was also reported in other studies completed in tropical environments (Vercellino \& Bicudo, 2006; Pellegrini \& Ferragut, 2012).

Light is a limiting resource for periphytic algae as well as nutrients, and can act interactively, where by increasing the supply of one of these limiting resources we find a corresponding increase in demand for another resource (Taulbee et al., 2005). Analyzing the variations between the abiotic components, we can observe that there were no great changes among the treatments during the experiment period, so that the increase or limitation of the light incidence did not affect the nutrient demand significantly.

The largest changes in the abiotic variables occurred at the end of the experiment, mainly with the variables of total nitrogen, conductivity and turbidity. The total nitrogen variable underwent a small change and the easily assimilated forms of nitrogen, such as ammoniacal nitrogen and nitrate (Esteves \& Amado, 2011) did not present significant change. This increase did not influence the biomass of the community in this experiment. The increase in conductivity may be related to rain that fell the night before the last day of the experiment. The turbidity increase at the end of the experiment may be related to the mechanical degradation, chemical and/or biological transformations of material present in the environment, and can be considered a controlling factor of the colonization process (Felisberto \& Rodrigues, 2012).

Thus, we conclude that light is a variable with direct influence on the periphytic biomass. At low intensity, which may be due to the presence of the macrophyte bank, riparian forests, turbidity of water bodies, for example, it is a variable that can limit the production of biomass. In high intensity however, it influences by increasing its production.

\section{Acknowledgements}

We thank the Conselho Nacional de Desenvolvimento Científico e Tecnológico (CNPq) for the provision of $\mathrm{PhD}$ scholarship to Helivania
Sardinha dos Santos and scientific productivity to Liliana Rodrigues.

\section{References}

AGOSTINHO, A.A., PELICICE, F.M. and GOMES, L.C. Dams and the fish fauna of the Neotropical region: impacts and management related to diversity and fisheries. Brazilian Journal of Biology = Revista Brasileira de Biologia, 2008, 68(4, Suppl), 1119-1132. http://dx.doi.org/10.1590/S151969842008000500019. PMid:19197482.

ANTOINE, S.E. and BENSON-EVANS, K. The effect of light intensity and quality on the growth of benthic algae. I. Phytopigment variations. Archiv für Hydrobiologie, 1983a, 98, 299-306.

ANTOINE, S.E. and BENSON-EVANS, K. The effect of light intensity and quality on the growth of benthic algae. II. Population dynamics. Archiv für Hydrobiologie, 1983b, 99, 118-128.

BOSTON, H.L. and HILL, W.R. Photosynthesislight relations of stream periphyton communities. Limnology and Oceanography, 1991, 36(4), 644656. http://dx.doi.org/10.4319/lo.1991.36.4.0644.

CADWELL, M.M., BJÖRN, L.O., BORNMAN, J.F., FLINT, S.D., KULANDAIVELU, G., TERAMURA, A.H. and TEVINI, M. Effects of increased solar ultraviolet radiation on terrestrial ecosystems. Journal of Photochemistry and Photobiology B: Biology (Basel), 1998, 46, 40-52.

CATTANEO, A., GALANTI, G., GENTINETTA, $S$. and SUSANA, A. Epiphytic algae and macroinvertebrates on submerged and floating-leaved macrophytes in an Italian lake. Freshwater Biology, 1998, 39(4), 725-740. http://dx.doi.org/10.1046/ j.1365-2427.1998.00325.x.

DODDS, W.K., HUTSON, R.E., EICHEM, A.C., EVANS, M.A., GUDDER, D.A., FRITZ, K.M. and GRAY, L. The relationship of floods, drying, flow and light to primary productions and producer biomass in a prairie stream. Hydrobiologia, 1996, 333(3), 151-159. http://dx.doi.org/10.1007/BF00013429.

ESTEVES, F.A. and AMADO, R. A radiação solar e seus efeitos em ecossistemas aquáticos continentais. In: F. A. ESTEVES, ed. Fundamentos de limnologia. 3. ed. Rio de Janeiro: Interciência/FINEP, 2011, pp. 239-258.

FELISBERTO, S.A. and RODRIGUES, L. Dinâmica sucessional de comunidade de algas perifíticas em um ecossistema lótico subtropical. Rodriguésia, 2012, 63(2), 463-473. http://dx.doi.org/10.1590/S217578602012000200018 .

FONTANA, D.C., ALVES, G.M., ROBERTI, D. MORAES, O.L.L. and GERHARDT, A. Estimativa da radiação fotossinteticamente ativa absorvida pela cultura da soja através de dados do sensor Modis. Agrometeorological, 2012, 71, 563-571. 
GINÉ, M.F., BERGAMIN F, H., ZAGATTO, E.A.G. and REIS, B.F. Simultaneous determination of nitrate and nitrite by flow injection analysis. Analytica Chimica Acta, 1980, 114, 191-197. http://dx.doi. org/10.1016/S0003-2670(01)84290-2.

GOLTERMAN, H.L., CLYMO, R.S. and OHMSTAD, M.A.M. Methods for physical and chemical analysis of freshwaters. Oxford: Blackwell Scientific, 1978.

GUARIENTO, R.D., CARNEIRO, L.S., CALIMAN, A., LEAL, J.J.F., BOZELLI, R.L. and ESTEVES, F.A. Food Web Architecture and basal resources interact to determine biomass and stoichiometric cascades along a benthic food web. PLoS One, 2011, 6(7), e22205. http://dx.doi.org/10.1371/journal.pone.0022205. PMid:21789234.

GUASCH, H. and SABATER, S. Light history influences the sensitivity to atrazine in periphytic algae. Journal of Phycology, 1998, 34(2), 233-241. http://dx.doi. org/10.1046/j.1529-8817.1998.340233.x.

HILL, W. Effects of light. In: R. J. STEVENSON, M. L. BOTHWELL and R. L. LOWE, eds. Algal ecology: freshwater benthic ecology. Cambridge: Academic Press, 1996, pp 121-148. http://dx.doi.org/10.1016/ B978-012668450-6/50034-5.

HILL, W.R. and BOSTON, H.L. Community development alters photosynthesis-irradiance relations in stream periphyton. Limnology and Oceanography, 1991, 36(7), 1375-1389. http:// dx.doi.org/10.4319/lo.1991.36.7.1375.

HILL, W.R. and FANTA, S.E. Phosphorus and light colimit periphyton growth at subsaturating irradiances. Freshwater Biology, 2008, 53(2), 215225.

HILL, W.R., RYON, M.G. and SCHILLING, E.M. Light limitation in a stream ecosystem: responses by primary producers and consumers. Ecology, 1995, 76(4), 1297-1309. http://dx.doi. org/10.2307/1940936.

KOROLEFF, K.J.H. Determination of ammonia. In: E. GRASSHOFF and E. KREMLING, eds. Verlog Chemie Wheinhein. New York: 1976, pp. 117-181.

KRUPEK, R.A., EMPINOTTI, A., SANTOS, K.R. and ARAÚJO, E.A.T. Influence of physical characteristics of environment (light and current velocity) on the substrate occupation by Spirogyra sp. in stream ecosystems. Brazilian Journal of Botany, 2014, 37(4), 453-459. http://dx.doi.org/10.1007/s40415-0140086-x.

MACKERETH, F.Y.H., HERON, J. and TALLING, J.F. Water analysis: some revised methods for limnologists. Cumbria: Freshwater Biological Association, 1978.

MURAKAMI, E.A. and RODRIGUES, L. Resposta das algas perifíticas às alteraçóes de temperatura $\mathrm{e}$ ao enriquecimento artificial de nutrientes em curto período de tempo. Acta Scientiarum. Biological Sciences, 2009, 31, 273-284.
MURAKAMI, E.A. Resposta das algas perifíticas da planície de inundação do alto Rio Paraná às alteraçóes de temperatura e ao enriquecimento artificial de nutrientes [Tese de doutorado em Ecologia de Ambientes Aquáticos Continentais). Maringá: Universidade Estadual de Maringá, 2008.

MURAKAMI, E.A., BICUDO, D.C. and RODRIGUES, L. Periphytic algae of the Garças Lake, Upper Paraná River floodplain: comparing the years 1994 and 2004. Brazilian Journal of Biology $=$ Revista Brasileira de Biologia, 2009, 69(2, Suppl), 459-468. http:// dx.doi.org/10.1590/S1519-69842009000300002. PMid:19738955.

PELLEGRINI, B.G. and FERRAGUT, C. Variação sazonal e sucessional da comunidade de algas perifíticas em substrato natural em um reservatório mesotrófico tropical. Acta Botanica Brasílica, 2012, 26(4), 810-821. http://dx.doi.org/10.1590/S010233062012000400010 .

RODRIGUES, L. and BICUDO, D.C. Similarity among periphyton algal communities in a lenticlotic gradient of the upper Paraná river floodplain, Brazil. Revista Brasileira de Botanica. Brazilian Journal of Botany, 2001, 24(3), 235-248. http://dx.doi. org/10.1590/S0100-84042001000300001.

SANCHES, L.F., GUARIENTO, R.D., CALIMAN, A., BOZELLI, R.L. and ESTEVES, F.A. Effects of nutrients and light on periphytic biomass and nutrient stoichiometry in a tropical black-water aquatic ecosystem. Hydrobiologia, 2011, 669(1), 3544. http://dx.doi.org/10.1007/s10750-011-0661-0.

STATSOFT INC. Statistica (data analysis software system), version 7.1. USA: StatSoft Inc.,2005 [viewed 7 May 2018]. Available from: www.statsoft.com

TAULBEE, W.K., COPPER, S.C. and MELACK, J.M. Effects of nutrient enrichment on algal biomass across a natural light gradient. Archiv für Hydrobiologie, 2005, 164(4), 449-464. http://dx.doi. org/10.1127/0003-9136/2005/0164-0449.

VADEBONCOEUR, Y. and STEINMAN, A.D. Periphyton function in lake ecosystems. TheScientific WorldJournal, 2002, 2, 1449-68. http:// dx.doi.org/10.1100/tsw.2002.294. PMid:12805932.

VERCELLINO, I.S. and BICUDO, D.C. Sucessão da comunidade de algas perifíticas em reservatório oligotrófico tropical (São Paulo, Brasil): comparação entre período seco e chuvoso. Revista Brasileira de Botanica. Brazilian Journal of Botany, 2006, 29(3), 363-377. http://dx.doi.org/10.1590/S010084042006000300004

VIS, C., HUDON, C. and CARIGNAN, R. Influence of the vertical structure of macrophyte stands on epiphyte community metabolism. Canadian Journal of Fisheries and Aquatic Sciences, 2006, 63(5), 1014 1026. http://dx.doi.org/10.1139/f06-021.

WELLNITZ, T.A., RADER, R.B. and WARD, J.V. Importance of light and nutrients in structuring an 
algal community in a rocky mountain stream. Journal of Freshwater Ecology, 1996, 11(4), 399-413. http:// dx.doi.org/10.1080/02705060.1996.9664467.

WINKWORTH, C.L., SALIS, R.K. and MATTHAEI, C.D. Interactive multiple-stressor effects of the antibiotic monensin, cattle effluent and light on stream periphyton. Freshwater Biology, 2015, 60(11), 2410-2423. http://dx.doi.org/10.1111/ fwb. 12666 .

WOOD, R.J., MITROVIC, S.M., LIM, R.P. and KEFFORD, B.J. The influence of reduced light intensity on the response of benthic diatoms to herbicide exposure. Environmental Toxicology and
Chemistry, 2016, 35(9), 2252-2260. http://dx.doi. org/10.1002/etc.3379. PMid:26801964.

ZHAO, Y., XIONG, X., WU, C., XIA, Y., LI, J. and WU, Y. Influence of light and temperature on the development and denitrification potential of periphytic biofilms. The Science of the Total Environment, 2018, 613-614, 1430-1437. http:// dx.doi.org/10.1016/j.scitotenv.2017.06.117. PMid:28668307.

Received: 23 July 2020 Accepted: 20 April 2021

Associate Editor: Ronaldo Angelini. 